\title{
Management of Anaemia of Chronic Kidney Disease Complicated with Allo-Immunization in Sickle Cell Anaemia Using Double- Dose Erythropoietin: A Case Report
}

\author{
Madu $\mathrm{AJ}^{1}$ and Ughasoro $\mathrm{MD}^{2}$ \\ ${ }^{1}$ Department of Haematology and Immunology, University of Nigeria Enugu Campus, Nigeria \\ ${ }^{2}$ Department of Pediatrics, University of Nigeria Enugu Campus, Nigeria
}

*Corresponding author: Madu AJ, Department of Haematology and Immunology, University of Nigeria Enugu Campus, Nigeria, Tel: +2348037861784; Email: anazoeze.madu@unn.edu.ng

\section{Case Report}

Volume 4 Issue 1

Received Date: April 03, 2020

Published Date: April 13, 2020

DOI: $10.23880 /$ hij-16000156

\section{Abstract}

Chronic blood transfusion has been recorded in several cases of sickle cell due to background haemolysis. Significant end organ failure consequent upon chronic vaso-occlusion also occurs as a hallmark of the disease. Chronic kidney disease may occur as an end event arising from several pathogenetic disease processes involving the kidneys in sickle cell. This is a case of chronic kidney disease sickle cell disease in an adult female, who developed chronic kidney disease (CKD) post-delivery with consequent transfusion dependence. Occurrence of pan-agglutination and recurrent haemolysis post-transfusion further complicated the clinical picture. Patient however responded to a double dose (8,000 IU) of Erythropoieitin (Epo) and iron and has become transfusion-independent. Higher doses of Epo may be helpful in overcoming Epo-resistance in sickle cell disease with nephropathy.

Keywords: Chronic blood transfusion; Haemolysis; Sickle cell

Abbreviations: CKD: Chronic Kidney Disease; CKD: Chronic Kidney Disease; Epo: Erythropoieitin; ESA: Erythropoiesis Stimulating Agents.

\section{Introduction}

Chronic Kidney disease (CKD) in a patient with sickle cell disease can further compound the anaemia already present in these patients [1,2]. Co-existence of CKD in SCD patients increases the frequency they require blood transfusion and further increases the possibility of allo-immunization. Such patients are usually transfusion-dependent $[3,4]$. The benefit of use of erythropoietin (Epo) in sickle cell disease patients with CKD has been in doubt [4] with clear understanding of the pathogenesis of this Epo resistance.. It is hypothesized that the effect of chronic inflammatory cytokines, which have been discovered to be elevated in SCD maybe responsible $[5,6]$. This has been a major challenge to the use of Epo in the management of sickle cell patients with allo-immunization.
In this report, the effect of double dose Epo on the red cell mass in a SCD patient with CKD was presented.

\section{Case Presentation}

The patient was a 35 year female diagnosed with sickle cell disease since childhood. She developed preeclampsia with bilateral leg swelling and proteinuria with a rising blood pressure of $130 / 80 \mathrm{mmHg}$ by the $27 \mathrm{th}$ week and $140 / 90 \mathrm{mmHg}$ by the 29th week. She was severely anaemic with haemoglobin concentration $(\mathrm{Hb})$ of $6.4 \mathrm{~g} / \mathrm{dL}$. She was transfused with 2 units of packed cells. Her other haematological parameters were; white cell count- $12.9 \mathrm{x}$ 109/L and platelet $538 \times 109 / \mathrm{L}$. The estimated GFR (CKDEPI) was $76 \mathrm{~mL} / \mathrm{min} / 1.73 \mathrm{~m} 2$, urinalysis showed $\mathrm{pH} 5$, protein +++ , blood positive, white cells 8-10 and red cells 2-3 per high power field. Renal scan showed nephropathy involving the right kidneys in pregnancy. She was delivered by elective $\mathrm{CS}$ at 34 weeks due to a progressively rising blood 


\section{Haematology International Journal}

pressure of $140 / 100 \mathrm{mmHg}$ and persistent proteinuria. Postdelivery her $\mathrm{Hb}$ continued to deteriorate, requiring repeated transfusion. Her renal function test has remained elevated with an estimated GFR of $37 \mathrm{ml} / \mathrm{min} / 1.73 \mathrm{~m} 2$ at the 8 th month post-delivery.

Following repeated transfusions she developed panagglutination with possible alloimmunization and therefore required to be transfused every 4-6 weeks after each bout of transfusion. She was placed on oral steroids as well as subcutaenous erythropoietin 4,000 units 3 times weekly with oral ferrous sulphate, furosemide and Lisinopril for 3 months with no change in her transfusion trend. She was placed on oral hydroxyurea as well as prednisolone also to no avail. On her last admission for transfusion 30 months after delivery she was commenced on a double-dose of Erythropoetin $(8,000$ units 3 times weekly) and her $\mathrm{Hb}$ appreciated $8.4 \mathrm{~g} / \mathrm{dL}$, wbc- $6.5 \mathrm{x} 109 / \mathrm{L}$ and platelet $-389 \mathrm{x}$ $109 / \mathrm{L}$ and she has not been transfused in the past 4 months though her GFR remains $32 \mathrm{ml} / \mathrm{min} / 1.73 \mathrm{~m} 2$.

Anaemia in chronic kidney disease (CKD) is usually secondary to reduction in erythropoietin production and in non-SCA patients is treated with Epo and iron therapy. This modality of treatment is usually not rewarding in patients with SCA and CKD. The pathogenesis of failure of this treatment failure has not been fully understood but may be due to the "inflammation-like" background which occurs in SCA. This then mimics, in part, the picture seen in anaemia of chronic disease, which in some cases does not respond to Epo therapy. Doubling the Epo dose was found to have helped overcome the resistance in this case.

\section{Discussion}

Sickle cell anaemia is a chronic haemolytic state complicated by end organ damage due to vaso-occlusion [7]. This predisposes patients with severe disease to end organ damage and other chronic complications which may worsen their anaemia and increase their transfusion demand [8]. Repeated transfusions lead to consequent haemolytic transfusion reactions and complications. Chronic kidney disease in sickle cell worsens their anaemia and increases their transfusion needs as was observed in our index patient $[2,9]$. Early nephropathy, marked by micro-albuminuria is usually managed with angiotensin-converting enzyme inhibitors in patients living with sickle cell $[10,11]$. This was earlier instituted in the index patient and continued throughout. In CKD patients, erythropoietin (Epo) is routinely used to treat anaemia secondary to this condition. However, some degree of erythropoietin resistance has been observed in sickle nephropathy [4]. The case report showcases a typical case of sickle nephropathy who was not responding to standard doses of Epo. Several pathogenetic mechanisms have been proposed to cause this erythropoietin resistance in this scenario $[12,13]$.

Sickle cell disease complicated with chronic kidney disease therefore contributes to the increased propensity to develop alloimmunization $[3,14]$. In our index patient the pregnant state and the peuperal stress might have contributed to the development or worsening of her nephropathy and consequent transfusion-dependence. Alloimmunization has also been observed in CKD patients following repeated transfusions and is therefore not peculiar to SCA patients $[15,16]$. Development of allo-antibodies is thought to be influenced and potentiated further by the inflammatory state observed in sickle cell [6]. The offending antibodies in alloimmunization have been noted to be antiKell, RhE and Duffy antibodies in a previous studies $[17,18]$. The use of steroids is usually unrewarding and Eculizimab (a monoclonal antibody) may help in some situations [19]. The new monoclonal antibodies and rather expensive and were not available for the treatment of this patient. This development becomes inevitable in certain clinical scenarios as observed in our patient. Epo resistance has also been noted in CKD to be due to iron deficiency, inflammation, poor nutritional state and use of angiotensin receptor blockers [16].

Anaemia of chronic inflammation is also known to be erythropoietin resistant in most situations due to the high levels of hepcidin, a pro-inflammatory hormone, secreted by the liver. The action of hepcidin on the marrow macrophages leads to the so called "reticulo-endothelial iron block" which causes anaemia despite adequate plasma iron and Epo $[18,20]$. The levels of Epo in sickle cell patients has been noted not to be commensurate with the degree of anaemia in them [21]. This may imply that increase in Epo levels may still be able to initiate increased erythropoiesis in these situations. This mechanism may be responsible for the Epo-resistance observed in SCD patients, as sickle cell disease is also known to cause elevation of pro-inflammatory cytokines. Variations in dosing schedule of erythropoiesis stimulating agents (ESA) had been noted to impact on development of transfusionindependence in patients with myelodysplastic syndrome [22]. Similar dosing schedules have not been routinely used in other situations where erythropoietin -resistance has been known to occur. In our index patient double he dose of Epo $(8,000 \mathrm{IU})$ was given three times weekly in an attempt to override this resistance and this was successful in driving erythropoiesis and markedly reduce transfusion demand.

\section{Conclusion}

The use of higher doses of Epo may be beneficial in sickle cell anaemia patients requiring repeated transfusion to solve the issue of alloimmunization. 


\section{Haematology International Journal}

\section{References}

1. Madu AJ, Ubesie A, Ocheni S, Chinawa J, Madu KA, et al. (2015) Important clinical and laboratory correlates of glomerular filtration rate in sickle cell anemia. Niger J Clin Pract 18(5): 633-637.

2. Yeruva SL, Paul Y, Oneal P, Nouraie M (2016) Renal Failure in Sickle Cell Disease: Prevalence, Predictors of Disease, Mortality and Effect on Length of Hospital Stay. Hemoglobin 40(5): 295-299.

3. Habibi A, Mekontso-Dessap A, Guillaud C, Michel M, Razazi K, et al. (2016) Delayed hemolytic transfusion reaction in adult sickle-cell disease: presentations, outcomes, and treatments of 99 referral center episodes. Am J Hematol 91(10): 989-994.

4. Boyle SM, Jacobs B, Sayani FA, Hoffman B (2016) Management of the Dialysis Patient with Sickle Cell Disease. Semin Dial 29(1): 62-70.

5. Campbell-Lee SA, Kittles RA (2014) Red blood cell alloimmunization in sickle cell disease: Listen to your ancestors. Transfus Med Hemother 41(6): 431-435.

6. Fasano RM, Booth GS, Miles M, Du L, Koyama T, et al. (2015) Red blood cell alloimmunization is influenced by recipient inflammatory state at time of transfusion in patients with sickle cell disease. Br J Haematol 168(2): 291-300.

7. Adegoke SA, Adeodu 00, Adekile AD (2015) Sickle cell disease clinical phenotypes in children from SouthWestern, Nigeria. Niger J Clin Pract 18(1): 95-101.

8. Nielsen L, Canoui-Poitrine F, Jais JP, Dahmane D, Bartolucci P, et al. (2016) Morbidity and mortality of sickle cell disease patients starting intermittent haemodialysis: a comparative cohort study with nonSickle dialysis patients. Br J Haematol 174(1): 148-152.

9. Nath KA, Hebbel RP (2015) Sickle cell disease: renal manifestations and mechanisms. Nat Rev Nephrol 11(3): 161-71.

10. Sasongko TH, Nagalla S, Ballas SK (2015) Angiotensinconverting enzyme (ACE) inhibitors for proteinuria and microalbuminuria in people with sickle cell disease. Cochrane Database Syst Rev 2015(6): CD009191.

11. Roy NB, Fortin PM, Bull KR, Doree C, Trivella M, et al. (2016) Interventions for chronic kidney disease in people with sickle cell disease. Cochrane Database Syst Rev 2016(10).

12. Karafin MS, Koch KL, Rankin AB, Nischik D, Rahhal G, et al. (2015) Erythropoietic drive is the strongest predictor of hepcidin level in adults with sickle cell disease. Blood Cells Mol Dis 55(4): 304-307.

13. Garrido P, Ribeiro S, Fernandes J, Vala H, Bronze-daRocha E, et al. (2015) Iron-hepcidin dysmetabolism, anemia and renal hypoxia, inflammation and fibrosis in the remnant kidney rat model. PLoS One 10(4): e0124048.

14. Kangiwa U, Ibegbulam O, Ocheni S, Madu A, Mohammed $N$ (2015) Pattern and prevelence of alloimmunization in multiply transfused patients with sickle cell disease in Nigeria. Biomark Res 3: 26.

15. Matteocci A, Pierelli L (2014) Red blood cell alloimmunization in sickle cell disease and in thalassaemia: current status, future perspectives and potential role of molecular typing. Vox Sang 106(3): 197208.

16. Obi EI, Pughikumo CO, Oko-Jaja RI (2018) Red blood cell alloimmunization in multi-transfused patients with chronic kidney disease in Port Harcourt, South-South Nigeria. Afr Health Sci 18(4): 979-987.

17. Meda E, Magesa PM, Marlow T, Reid C, Roberts DJ, et al. (2014) Red Blood Cell Alloimmunization in Sickle Cell Disease Patients in Tanzania. East Afr J Public Health 11(2): 775-780.

18. Madu AJ, Ughasoro MD (2017) Anaemia of Chronic Disease: An In-Depth Review. Med Princ Pract 26(1): 1-9.

19. Pirenne F, Bartolucci P, Habibi A (2017) Management of delayed hemolytic transfusion reaction in sickle cell disease: Prevention, diagnosis, treatment. Transfus Clin Biol 24(3): 227-231.

20. Blanchette NL, Manz DH, Torti FM, Torti SV (2016) Modulation of hepcidin to treat iron deregulation: potential clinical applications. Expert Rev Hematol 9(2): 169-186.

21. Pulte ED, McKenzie SE, Caro J, Ballas SK (2014) Erythropoietin levels in patients with sickle cell disease do not correlate with known inducers of erythropoietin. Hemoglobin 38(6): 385-389.

22. Duong VH, Baer MR, Hendrick F, Weiss SR, Sato M, et al. (2015) Variations in erythropoiesis-stimulating agent administration in transfusion-dependent myelodysplastic syndromes impact response. Leuk Res $39(6): 586-591$. 